Trinity University

Digital Commons @ Trinity

Health Care Administration Faculty Research

Health Care Administration

Winter 1998

\title{
Union Wages, Rents, and Skills in Health Care Labor Markets
}

Barry T. Hirsch

Edward J. Schumacher

Trinity University, eschumac@trinity.edu

Follow this and additional works at: https://digitalcommons.trinity.edu/hca_faculty

Part of the Medicine and Health Sciences Commons

\section{Repository Citation}

Hirsch, B.T. \& Schumacher, E.J. (1998). Union wages, rents, and skills in health care labor markets. Journal of Labor Research, 19(1), 125-147. doi: 10.1007/s12122-998-1006-2

This Article is brought to you for free and open access by the Health Care Administration at Digital Commons @ Trinity. It has been accepted for inclusion in Health Care Administration Faculty Research by an authorized administrator of Digital Commons @ Trinity. For more information, please contact jcostanz@trinity.edu. 


\title{
Union Wages, Rents, and Skills in Health Care Labor Markets*
}

\author{
BARRY T. HIRSCH
}

Florida State University, Tallahassee, FL 32306

\section{EDWARD J. SCHUMACHER}

East Carolina University, Greenville, NC 27858

We examine the effect of unions on the earnings of health care workers, with emphasis on the measurement and sources of union wage premiums. Using data constructed from the 1973 though 1994 Current Population Surveys, standard union premium estimates are found to be substantially lower among workers in health care than in other sectors of the economy, and to be smaller among higher skill than among lower skill occupational groups. Longitudinal analysis of workers switching union status, which controls for worker-specific skills, indicates a small impact of unions on earnings within both high and low skilled health care occupations. Evidence is found for small, but significant, union threat effects in health care labor markets. It has been argued that recent legal changes in bargaining unit determination should enhance union organizing and bargaining power: Although we cannot rule this out, such effects are not readily apparent in our data.

\section{Introduction}

During the last decade, registered nurses (RNs) and, to a lesser extent, other health care personnel have realized significant wage gains relative to similar workers outside the health care sector. Not well understood is the role of labor unions in the determination of earnings in health care labor markets. Past estimates of union-nonunion wage differentials suggest that union premiums are rather small (Adamache and Sloan, 1982; Bruggink et al., 1985; Cain et al., 1981; Feldman and Scheffler, 1982). Recent changes in the interpretation of labor law by the NLRB, however, have raised the possibility of increased union activity and bargaining power among health care workers. The growth of managed care, which has focused attention on staffing and labor costs (e.g., Rosenthal, 1996), has generated renewed interest among health care workers in union representation. Moreover, the AFL-CIO has recently indicated that the health care industry will be a major focus of its organizing efforts. Understanding the past impact of unions in health care labor markets, therefore, is crucial for assessing prospects for the future.

One of the more comprehensive studies on unions in health care labor markets is by Cain et al. (1981), who focus exclusively on hospitals. The authors utilize three 
alternative data sets: the Current Population Surveys for May 1973-1976, four Industry Wage Surveys between 1966 and 1975, and the 1976 Guide of the American Hospital Association, supplemented with a survey conducted by the authors. Cain et al. find small union-nonunion wage differentials among hospital employees in general, with about a 3 percent premium among private sector RNs. They also examine the possibility of union threat effects, finding evidence that unions increase the wages of both union and nonunion workers. Their hospital data suggest that a doubling of union density among private sector non-professional workers from 20 to 40 percent would increase both union and nonunion wages by 5 to 13 percentage points.

Other studies have found smaller union premiums for nurses than for lower skilled health care occupations, and lower premiums for hospital workers than for similar workers in nonhealth care settings. For example, Feldman and Scheffler (1982) examined how the union premium changes with age of the union and found that membership in a union less than eight years old increases $\mathrm{RN}$ wages by about 6 percent and licensed practical nurse (LPN) wages by about 8 percent (membership in older unions resulted in larger differentials). Secretaries and housekeepers, in contrast, realized premiums of about 13 percent. Hirsch and Schumacher (1995) obtained union premiums for all RNs of about 3 percent (and for hospital RNs about 2 percent), while for LPNs and nursing aides they obtained union premium estimates of 4.6 and 12.4 percent. With the exception of Hirsch and Schumacher, whose focus is on monopsony and not the union wage premium, these studies utilized data sets from the 1970s, focused on a narrow geographic area, or are limited by small sample sizes. None of the previous studies employed panel data to estimate union premiums.

We examine the role of unions in health care labor markets, with a special emphasis on nursing. ${ }^{1}$ Using data from 1973 through 1994, we provide evidence showing the extent of unionization, changes over time in union organizing activity, the magnitude of the union wage premium, and the effect of union density on union and nonunion wages for selected occupations in the health care industry. Sources of the union premium are then examined. By utilizing the longitudinal structure of the Current Population Survey (CPS) the union-nonunion differential is decomposed into a part representing an equalizing differential for (otherwise unmeasured) worker skill, and a part representing rents, enhancing our understanding of the source of the union wage differential. The paper provides an updated analysis of the role of unions in health care labor markets, examines how changes in labor law have influenced the bargaining power of health care unions, and provides insight into the possible effects of the AFL-CIO's planned focus on organization in the health care sector.

Two standard findings in the empirical literature are that economy-wide union wage differentials are substantially lower for high-skilled workers than for low-skilled workers (Lewis, 1986; Hirsch and Schumacher, 1998) and that unionism is associated with lower wage dispersion (Freeman, 1980). Due to their representative nature and the political process within a union, the goals and actions of a union are likely to favor preferences of members with median preferences and, similarly, "average" workers are more likely to be organized. Because of contractual wage standardization, imply- 
ing less individual-based wage dispersion, workers with high ability find unions less attractive since they may earn higher wages in the nonunion sector. Those with low ability have difficulty acquiring union jobs since queues for these jobs allow employers to be selective (Abowd and Farber, 1982). The implication of differential matching in union and nonunion jobs is that in lower skilled occupations, union establishments will tend to hire relatively high-ability workers, as compared to nonunion establishments. In high-skill occupations, union work sites will attract workers with relatively low ability, as compared to nonunion work sites. The implications of this type of labor market sorting for the measurement of union wage premiums among health care workers will be examined.

In the next section, we present detailed cross-sectional evidence on unionnonunion wage differentials and the effects of union density on union and nonunion wages among RNs, health technicians, and health service workers. Section III provides longitudinal wage change analysis that permits a decomposition of the union premium into skill- and nonskill-related components. We review in Section IV recent changes in labor law relating to the health care sector and provide descriptive evidence on union organizing and membership density. Conclusions follow in Section V.

\section{Cross-Sectional Evidence on the Union Premium}

Data and Descriptive Evidence. Our cross-sectional data are drawn from the May CPS for 1973 through 1981, and the monthly CPS Outgoing Rotation Group (ORG) earnings files for January 1983 through December 1994. Between 1973 and 1978 the earnings supplement was conducted once a year in May, but all persons in the sample were administered the questions. In 1979, a half sample of the May CPS contains both earnings and union information, while only quarter samples are available for 1980 and 1981. There was no union question in 1982. Beginning in 1983, union status questions were added to the earnings supplement administered each month to a quarter sample (i.e., the outgoing rotation groups) of the CPS (monthly earnings supplements, absent the union status questions, began in January 1979).

Included in our sample are employed wage and salary workers ages 18 or over whose major activity in the week prior to the survey was not schooling. The wage is calculated as usual weekly earnings on the primary job (inclusive of tips, commissions, and overtime) divided by usual hours worked per week. For those small number of workers whose weekly earnings are top-coded (at \$999 through 1988 and $\$ 1,923$ beginning in 1989), we assign the estimated mean earnings above the cap based on the assumption that the upper tail is characterized by a Pareto distribution. ${ }^{2}$ We omit from the sample workers with implicit hourly earnings of less than $\$ 1$ or more than $\$ 99.99$ December 1994 dollars. Further sample restrictions, discussed subsequently, are imposed for the longitudinal analysis.

In Table 1, descriptive data are presented on mean real wages (in December 1994 dollars) by union status, union membership density, and the unadjusted unionnonunion log wage differential. These figures are provided for a pooled 1973-1994 
Table 1

Mean Real Wages, Union Density, and the Unadjusted Union Wage Gap by Occupation

\begin{tabular}{|c|c|c|c|c|c|}
\hline & $w_{U}$ & $w_{N}$ & Density & $\ln W_{U}-\ln W_{N}$ & $N$ \\
\hline \multicolumn{6}{|l|}{ Health Care Workers: } \\
\hline Registered Nurses & 18.00 & 16.43 & 0.157 & 0.096 & 38,555 \\
\hline Health Technicians & 13.11 & 12.18 & 0.106 & 0.090 & 29,594 \\
\hline $\begin{array}{l}\text { Health Service } \\
\text { Occupations }\end{array}$ & 9.73 & 7.88 & 0.141 & 0.223 & 45,044 \\
\hline \multicolumn{6}{|c|}{ Non-Health Workers in Health Industry: } \\
\hline School $\geq 16$ & 15.72 & 14.23 & 0.095 & 0.144 & 11,576 \\
\hline $13 \leq$ School $\leq 15$ & 11.38 & 9.88 & 0.085 & 0.160 & 16,324 \\
\hline School $\leq 12$ & 10.09 & 8.50 & 0.114 & 0.185 & 38,334 \\
\hline \multicolumn{6}{|c|}{ Non-Health Workers Outside Health Industry: } \\
\hline School $\geq 16$ & 17.77 & 17.57 & 0.210 & 0.094 & 316,194 \\
\hline $13 \leq$ School $\leq 15$ & 14.43 & 11.43 & 0.114 & 0.283 & 250,172 \\
\hline School $\leq 12$ & 12.50 & 9.24 & 0.128 & 0.342 & 507,847 \\
\hline
\end{tabular}

Notes: Data are from the May CPS supplements for 1973-1981 and the CPS ORG files for 1983-1994. Union data are not available in the CPS for 1982. $W_{U}$ and $W_{N}$ are real wages (in December 1994 dollars) for union and nonunion workers, respectively. Density is the percentage of workers covered by a union contract. The unadjusted log wage differential is represented by $\ln W_{U}-\ln W_{N}$, and $N$ is the sample size. Health Technicians include clinical laboratory technologists and technicians, dental hygienists, health record technologists and technicians, radiologic technicians, licensed practical nurses, and health technologists and technicians n.e.c. Health Service Occupations include dental assistants, health aides, except nursing and nursing aides, orderlies, and attendants.

sample of three groups of health care workers based on high, medium, and low levels of skill. The groups are, respectively, registered nurses, health technologists and technicians, and health service occupations. ${ }^{3}$ For comparison, we also construct two sets of comparison groups in non-health occupations, one working within and the other outside the health care sector. These comparison groups consist of workers in the following broad occupational categories (with health occupations excluded): professional specialty occupations; technicians and related support; sales, administrative support, and clerical; and service occupations (except protective and household services). For example, secretarial and clerical workers employed in hospitals or the offices of physicians would be included in the health care sector control groups, while those employed outside the health care sector would be in the larger non-health care sector comparison groups. The groups are segmented by skill based on education. For a comparison to RNs, we select those with at least a 4-year college degree. For health technicians we select a medium skill comparison group of those with 
some college but not a 4-year degree, while for the health service occupations we select a lower skill comparison group that includes those with 12 years of schooling or less.

Over the 1973-1994 sample period, 15.7 percent of RNs are union members, with unionized $\mathrm{RN}$ wages $.096 \mathrm{log}$ points higher than among nonunion workers. ${ }^{4}$ Among the health technician sample, union density is lower and the unadjusted union wage gap is similar to that of RNs. By contrast, the unadjusted union differential of .223 among the lower skilled health service workers (e.g., nursing aides) is more than double that for RNs and technicians. Among non-health workers within the health care sector, we find a similar pattern to that of the nursing groups, although there is less variation across schooling levels. The large control groups of workers in non-health occupations employed outside the health care sector display the expected skill pattern of union premiums. The comparison group of college graduates has an unadjusted log wage gap of .094, as compared to .283 among the group with some college and .342 among those with a high school degree or less. With the exception of the high-skilled group, the descriptive evidence is consistent with relatively weaker union effects within health care than outside the health care sector.

The Cross-Sectional Union Differential. Table 2 displays regression estimates of union premiums for three groups of workers - health care workers (in turn divided into RNs, health technicians, and health service workers), workers in non-health occupations employed in health service industries, and non-health workers outside the health service sector. The latter two worker comparison groups are in turn divided into high-, medium-, and low-skill groups, proxied by completed years of schooling. The union-nonunion wage differential is estimated from a pooled log wage equation, with the coefficient on a membership dummy measuring the premium. ${ }^{5}$ The regressions include a dummy for hospital employment (for the health service industries samples), plus controls for years of schooling, potential experience and its square, and dummy variables for gender, race, marital status (2), part-time status, large metropolitan area, region (8), and year (14). ${ }^{6}$

Union wage effects are relatively small in the health care sector, similar to findings from most previous studies based on alternative data sources and earlier years. Following control for measurable characteristics, unionized RNs receive wages .032 log points higher than "similar" nonunion RNs. Unionized health technicians realize a .049 log point premium, while the differential within health service occupations is $.114 \log$ points. Workers in non-health occupations employed in the health care sector display union wage differentials of $.049, .075$, and .106 log points for the high-, medium-, and low-skill groups. Among the large comparison groups of non-health workers outside the health care sector, estimated union premiums are $.031, .154$, and $.193 \mathrm{log}$ points among the high-, medium-, and low-skill (schooled) groups.

Table 2 also presents the wage differentials associated with hospital employment for the health care workers and non-health workers employed in the health care sector. Among all health and, to a lesser extent, non-health care occupations, hospital 
Table 2

Union and Hospital Log Wage Advantage for Health Care and Non-Health Workers

\begin{tabular}{ccc}
\hline & Union & Hospital \\
\hline Health Care Workers: & & \\
Registered Nurses & 0.032 & 0.159 \\
& $(0.005)$ & $(0.004)$ \\
Health Technicians & 0.049 & 0.067 \\
& $(0.007)$ & $(0.004)$ \\
Health Service & 0.114 & 0.146 \\
Occupations & $(0.005)$ & $(0.004)$
\end{tabular}

Non-Health Workers in Health Industry:

School $\geq 16$

$13 \leq$ School $\leq 15$

School $\leq 12$
0.049

0.075

$(0.010)$

0.106

(0.006)
0.087

(0.005)

(0.003)

Non-Health Workers outside Health Industry:

School $\geq 16$

$13 \leq$ School $\leq 15$

School $\leq 12$
0.031

0.154

(0.003)

0.193

$(0.002)$

Notes: Data are from the May CPS supplements for 1973-1981 and the CPS ORG files for 1983-1994. Estimates are based on union and hospital coefficients from wage level regressions with $\ln W$ as the dependent variable. Other variables included in the regressions are years of schooling, potential experience and its square, dummies for public employment, race (2), gender, marital status (2), large metropolitan area, part-time status, region (8) and year (14). The comparison group regressions included 4 occupational dummy variables. Full regression results for the nursing groups are presented in Appendix 1. Standard errors are in parentheses.

employees realize a wage advantage relative to non-hospital employees. The hospital premium is particularly large among RNs. Elsewhere we have shown that the hospital premium for RNs results from a combination of higher unmeasured skills among hospital nurses, more demanding working conditions, and, more problematically, receipt of quasi-rents during a period of increasing employment (Schumacher and Hirsch, 1997). 
In Appendix 1, wage equation coefficients on other variables are shown for the three health service groups. Schooling coefficients are relatively small within the narrowly defined occupational groups, since these reflect only within-occupation rates of return. Black health sector workers earn less than white workers, with the racial gap here being somewhat larger than the economy-wide gap observed among women (but not men). Although male workers earn a substantial premium in non-health-related occupations, differences in wages by gender within health occupations are small. In contrast to the large penalty for part-time workers in non-health occupations, there is little or no difference in wages between full-time and part-time health care workers.

Although our analysis focuses on wages, note that unions affect fringe benefits as well. In results not shown we examine fringe benefits by utilizing the March CPS supplements, which contain data on pensions and health insurance coverage. Consistent with economy-wide evidence (Freeman, 1981), we find among all the health (and non-health) occupations a greater likelihood among union than nonunion workers that the employer will both offer a pension and that the worker will participate. Similar to the evidence on wages, union-nonunion differences in pensions are larger for lower skilled than higher skilled occupational groups. Union workers also are more likely than nonunion workers to be offered health insurance and, among those offered insurance, to have part of the premium paid by the employer.

In this section we have seen that union wage differentials in the health care sector are small in both absolute terms and relative to the differentials found among the comparison groups of workers. Union power is typically displayed through both increased membership and wages, although wage premiums and membership are inversely related for a given level of union power (e.g., a movement along a labor demand constraint versus an outward shift of the constraint). While health care unions have union density levels not dissimilar from their comparison groups, their apparent small effect on wages suggests that bargaining power is limited. Prior to concluding that bargaining power in health care markets is weak, however, one must examine the effects of unions on nonunion wages.

Union Threat Effects. The evidence to this point suggests that unionized RNs earn about 3-4 percent higher wages than similar nonunion RNs. It cannot be assumed, however, that the absence of unions would cause average $\mathrm{RN}$ wages to converge to the current nonunion level, since unions have a potential influence on nonunion as well as union wages. The union impact on nonunion wages can be classified into labor spillover, demand, and union threat effects. Spillover and demand effects result in lower wages in the nonunion sector due, in the former case, to a wage-induced movement of employment out of the union and into the nonunion sector, and in the latter, to decreased industry demand for all inputs in the event that industry-wide product prices increase. Threat effects, however, produce a positive relationship between nonunion wages and union density, as nonunion employers increase wages to deter organizing. Evidence on the effect of unions on nonunion wages typically reveals the dominance of threat effects, as evinced by a positive relationship of nonunion wages and industry union density, while finding little evidence 
for large spillover or demand effects on nonunion wages (Hirsch and Addison, 1986; for contrasting evidence, see Neumark and Wachter, 1995).

In order to examine the effect of unionization on the wages of nonunion health professionals, we examine how wages vary with local labor market health care union density. Beginning with the October 1985 CPS, the Census identified 202 Metropoli$\tan$ Statistical Areas (MSAs) with populations of 100,000 or more (the largest areas are Consolidated Metropolitan Statistical Areas). Here, we assign each worker in the CPS to one of 252 market areas - the 202 MSAs plus 50 nonmetropolitan state groups. We then calculate area-specific union densities for the entire health care sector over the October 1985 to December 1994 period, allowing these values to proxy relative inter-area differences in health care union organizing strength (similar results are obtained when we delete observations where cell sizes are small).

Table 3 presents the individual union dummy and area union density coefficients (the latter interacted with individual union status) from log wage equations for the three groups of health care workers. The results indicate rather clear-cut union threat effects, with a tendency toward stronger density effects on nonunion than union wages and stronger threat effects among lower skilled health occupations than among RNs. For example, a unionized RN in a labor market with 25 percent union density will have wages $.014 \log$ points higher than a unionized $\mathrm{RN}$ in a market with 5 percent union density (a density effect of .068 times .20). Wages for nonunion RNs

Table 3

Union Threat Effects

\begin{tabular}{lcccc}
\hline & Union & $U^{*} \overline{\text { Den }}$ & $N^{*}$ Den & $p$-value \\
\hline Registered Nurses & 0.044 & 0.068 & 0.127 & 0.233 \\
& $(0.012)$ & $(0.046)$ & $(0.030)$ & \\
Health Technicians & 0.049 & 0.198 & 0.250 & 0.441 \\
& $(0.017)$ & $(0.067)$ & $(0.036)$ & \\
Health Service Occupations & 0.124 & 0.204 & 0.297 & 0.073 \\
& $(0.014)$ & $(0.051)$ & $(0.029)$ & \\
Non-Health Workers in & 0.074 & 0.327 & 0.252 & 0.130 \\
Health Care Industry & $(0.013)$ & $(0.049)$ & $(0.024)$ &
\end{tabular}

Notes: Data are from the October 1985-December 1994 CPS ORG files. $U^{*}$ Den and $N^{*}$ Den are coefficients on union density interacted with union and nonunion status, respectively. Union density is calculated for health industry sector workers in 202 standard metropolitan statistical areas and 50 non-MSA state areas. The $p$-value is for the hypothesis that the coefficients on density are equal for union and nonunion members. Other variables included in the regressions are schooling, potential experience and its square, and dummies for marital status (2), gender, race (2), region (8), large metropolitan area, part-time status, and year (7). Regressions for health care workers include a dummy for hospital employment. 
will be an estimated .025 higher in the more unionized labor market. Union threat effects for health technicians and other health service occupations are substantially larger, as are union wage premiums. In short, estimated union-nonunion wage differentials understate the total impact of labor unions on the wages of union and nonunion health care personnel. In results not shown, we find that union density effects were stronger after 1991 than prior to 1991 (e.g., a 20 percent increase in union density would increase nonunion wages by about 2 percent before and 3 percent after 1991). The year 1991 is significant because that is when the Supreme Court affirmed the NLRB's rulemaking policy with respect to hospital bargaining units. Changes in the legal framework are discussed later.

\section{Longitudinal Analysis of the Union Premium}

The cross-sectional estimates of health sector union wage premiums reported above are similar to those found in previous studies based on less recent data. Prior studies, however, have not been able to evaluate whether the union-nonunion wage differential represents a rent to union workers or a compensating differential for unmeasured differences in skills. If worker skills are not adequately measured by the standard variables, and omitted human capital is correlated with union status, then the union coefficient will be a biased measure of the union premium (Brown, 1980). Jakubson (1991), among others, presents evidence that this is the case for the economy as a whole. In this section we use the panel structure of the CPS to determine the extent of such bias, and to obtain estimates of the union premium net of worker-specific skill differences.

The Wage Change Model and CPS Panel Data. Below, we modify a standard logwage earnings equation to account for unmeasured worker-specific skill differences fixed over a one-year period. Letting $\Gamma_{i}$ represent the fixed effect on log wages for worker $i$ and adding a time subscript $t$, the log wage equation estimated above can be written as:

$$
\ln W_{i t}=\Sigma \beta_{j} X_{j i t}+\theta U N I O N_{i t}+\Sigma \tau_{y} Y E A R_{y i t}+\Gamma_{i}+e_{i t},
$$

where $\ln W_{i t}$ is the log real wage of worker $i$ in year $t ; X$ consists of variables (indexed by $j$ ) measuring personal and job related characteristics; $\beta$ are the respective coefficients; UNION is a dummy variable equal to one if the worker is a union member while $\theta$ is a measure of the union-nonunion log wage differential; and YEAR includes year dummies (indexed by $y$ ). The error term is divided into an individualspecific quality component $\left(\Gamma_{i}\right)$ assumed fixed over time (one year with our data) and a random, well behaved, component $\left(e_{i t}\right)$. If the omitted fixed effect is positively correlated with union status (i.e., more able workers are selected into union jobs), then estimates of the union wage premium from equation 1 are biased upward.

Letting the symbol $\Delta$ represent changes between adjacent years, a wage change equation will take the form (dropping the individual subscript $i$ ):

$$
\Delta \ln W_{d}=\Sigma \beta_{j} \Delta X_{j d}+\theta \Delta U N I O N_{d}+\Sigma \tau_{d} P E R I O D_{d}+\Delta e_{d},
$$


where $d$ indexes the time period over which changes are calculated, and PERIOD are dummies for the periods 1984/5 through 1993/4 (with 1983/4 the reference period) which capture differences in real wage growth across years. In equation 2 , the effects owing to unmeasured ability fall out, potentially allowing for unbiased estimates of the union premium, assuming that ability is equally valued at the margin by employers in both sectors (Gibbons and Katz, 1992) and within a year's time (i.e., skills are fully transferable). The estimate of the union premium is based on the change in wages for individuals who either switch into or out of union membership (we subsequently address the possibility of measurement error in the union change variable). If the union premium is due entirely to unions attracting higher ability workers, then the estimate of $\theta$ in the wage change equation should be zero, assuming marginal products are equivalent across sectors. ${ }^{7}$

In order to estimate equation 2, panel data with observations on individuals in at least two periods are required. As described above, the CPS earnings supplement questions are asked of individuals in the same month for consecutive years (i.e., rotation group 4 in year $t$ and rotation group 8 in year $t+1$ ). CPS panels for the year-pairs 1983/84 through 1993/94 provide unusually large files for longitudinal analysis, including sufficient numbers of union status switchers among nurses and other health professionals. Appendix 2 describes how the panel data set is constructed. Because the Census reinterviews households in fixed locations, individuals whose households move or who move out of a household during the year are not represented in the sample (young workers are most likely to be eliminated). In order to minimize measurement error in the longitudinal sample, individuals for whom the Census has allocated values of industry, occupation, eamings, or union status (the union allocation flag is available only since 1989) in either year $t$ or $t+1$, and those few workers displaying unusually large log wage changes (less than -1.0 or greater than 1.0), are deleted from the sample. The occupational samples (i.e., RNs, health technicians, and health service workers) include only workers employed in the same occupational category in both years, thus allowing us to focus on the wage effects associated with changes in union status. Although the longitudinal samples are not as representative of the employed labor force as are the cross-sectional samples, we obtain similar wage level equation results from the two samples.

Wage Change Estimates of Union Premiums. Table 4 presents the results of the "fixed effects" or wage change regression models estimated for the three groups of health care workers and their respective comparison groups. ${ }^{8}$ For comparison, the first column presents the union coverage coefficient from a standard log wage regression estimated in levels using observations from the second year in the panel. These estimates are similar to wage level estimates presented in Table 1 based on the larger samples. The second column displays wage change results. For RNs, the already small coefficient on union status falls from .032 in the levels regression to .011 in the wage change regression. The results for the other two groups of health care workers suggest that much of the cross-sectional union differential is in fact a compensating differential for unmeasured worker skills. Estimated union premiums for health tech- 
Table 4

\section{Wage Change Regression Results}

\begin{tabular}{|c|c|c|c|c|}
\hline & \multicolumn{2}{|c|}{ Registered Nurses } & \multicolumn{2}{|c|}{$\begin{array}{c}\text { Comparison Group } \\
\text { School } \geq 16\end{array}$} \\
\hline & $\ln W$ & $\Delta \ln W$ & $\ln W$ & $\Delta \ln W$ \\
\hline Union & $\begin{array}{c}0.032 \\
(0.009)\end{array}$ & - & $\begin{array}{c}0.064 \\
(0.008)\end{array}$ & - \\
\hline$\Delta$ Union & - & $\begin{array}{c}0.011 \\
(0.010)\end{array}$ & - & $\begin{array}{r}0.071 \\
(0.019)\end{array}$ \\
\hline Sample size & & & & \\
\hline
\end{tabular}

\begin{tabular}{|c|c|c|c|c|}
\hline & \multicolumn{2}{|c|}{ Health Technicians } & \multicolumn{2}{|c|}{$\begin{array}{c}\text { Comparison Group } \\
13 \leq \text { School } \leq 15\end{array}$} \\
\hline & $\ln W$ & $\Delta \ln W$ & $\ln W$ & $\Delta \ln W$ \\
\hline Union & $\begin{array}{c}0.042 \\
(0.015)\end{array}$ & - & $\begin{array}{c}0.174 \\
(0.006)\end{array}$ & - \\
\hline$\Delta$ Union & - & $\begin{array}{c}0.014 \\
(0.014)\end{array}$ & 一 & $\begin{array}{r}0.108 \\
(0.016)\end{array}$ \\
\hline Sample size & & & & \\
\hline
\end{tabular}

Health Service Occs

\section{Comparison Group}

School $\leq 12$

\begin{tabular}{lcccc} 
& $\ln W$ & $\Delta \ln W$ & $\ln W$ & $\Delta \ln W$ \\
\hline Union & 0.108 & - & 0.228 & - \\
& $(0.012)$ & & $(0.004)$ & \\
Unnion & - & 0.033 & - & 0.098 \\
& & $(0.012)$ & & $(0.011)$
\end{tabular}

Sample size

5,856

69,792

Notes: Data are from the CPS ORG panels from 1983/4 to 1993/4 (see Appendix 2). Columns under $\ln W$ are levels regressions using the log real wage in the second year as the dependent variable. Columns under $\Delta \ln W$ are wage change regressions using the change in the log real wage as the dependent variable. The comparison group excludes workers in the health care sector; these regressions include dummies for changing occupation. The change in union coefficient reported for the control group is for those who reported changing union status as well as occupation and industry. Dummies for the three other types of union changes were also included. See text for a description of the comparison groups. Other variable in the regressions are the change in hospital status (for the health occupations), change in public employment, change in part-time status, change in experience squared, and 9 period dummies. Standard errors are in parentheses. 
nicians fall from .042 to .014 as we move from a wage level to wage change equation, while premiums among health service workers (e.g., nursing aids) fall from .108 to .033 .

Were substantial measurement error in the union change variable not a real possibility, we would readily conclude that much of what is an already small wage advantage among unionized health care workers in fact reflects higher unmeasured skills among union than nonunion workers, rather than union bargaining power. Given that measurement error is likely to bias these coefficients toward zero, such a strong conclusion is not possible. More clear-cut is the finding that the longitudinal union estimates drop most sharply for the lower skilled health service group of workers. The implication is that among lower wage occupations, union wage standardization and employer selection lead to the matching of workers with high (unmeasured) skills into union jobs, as compared to nonunion workers with identical measured characteristics. What appears to be a substantial union premium among lower skill health care workers in fact largely reflects these differences in worker skills and not union bargaining power. Likewise, previous researchers have noted the particularly low union premiums for high-skilled health care workers, arguing that "nurses and other hospital workers may view collective bargaining as incompatible with the ethos of their professional mission, and where organized, they may be reluctant to exercise their bargaining power by traditional union pressure tactics" (Cain et al., p. 193). We offer a complementary explanation. Owing to within- and across-employer wage standardization, employers find it difficult to attract the most able RNs into union workplaces.

The selection by skill type that is hinted at among health care workers is readily evident in the economy-wide comparison group sample (Hirsch and Schumacher, 1998), where measurement error is not a major concern (see footnote 8). In contrast to the cross-sectional result of low union premiums among high-skill and large premiums among low-skill workers, the longitudinal estimates indicate similar union premiums of about .07 to $.11 \mathrm{log}$ points, with far smaller differences across skill groups than suggested by standard wage level analysis. These results indicate that union employers are able to select relatively high quality union (as compared to nonunion) workers with low levels of measured skills, while the most able among workers with high measured skills are not likely to be in the union queue. In short, unionization is associated with a relatively compressed distribution of worker skills, as compared to the skill distribution among nonunion workers.

\section{The Legal Structure and Changes over Time in Union Organizing and Density}

Our evidence indicates that unions have had rather modest effects on the wages of health care workers. This section identifies recent changes in the legal structure surrounding union organizing in hospitals and examines possible implications of these changes. Prior to the mid-1970s, unionization in hospitals and much of the health 
care sector was limited. Federal hospitals were first covered by the National Labor Relations Act (NLRA) in January 1962 by Executive Order 10988. A series of cases decided by the National Labor Relations Board (NLRB) in 1967 extended its jurisdiction to most private for-profit hospitals. The most important spur to union organizing was Public Law 93-360, passed on August 25, 1974, which brought voluntary nonprofit hospitals under coverage of the NLRA, while also including provisions that lengthened the strike notice period and required federal mediation of disputes. This law enabled the NLRB to conduct representation elections in hospitals and to mandate good faith bargaining. Union activity increased substantially after the passage of Public Law 93-360. The number of hospitals with at least one collective bargaining agreement increased from 912 in 1974 to 1,635 in 1977 (Feldman and Scheffler, 1982, p. 198). As seen in Table 5, elections in the health service industry increased from 248 in 1974, to 579 in 1975, and to a peak total of 746 in 1977 (NLRB Annual Reports). Union membership density in hospitals, based on our calculations from the CPS, increased from 13.0 percent in 1974, to 16.8 percent in 1981. Because the "flow" of new members from elections is typically small as compared to the "stock" of existing union employment, changes in organizing activity show up more rapidly in the NLRB election data than in the CPS union density figures.

Because of concern about work stoppages, Congress included an admonition in the committee notes to Public Law 93-360 to prevent undue proliferation of bargaining units in the health care industry (Mackender, 1992). They did not provide specific instructions, however, and the NLRB's approach to bargaining unit determination went through several stages. Initially the NLRB applied a "community-of-interest" doctrine to hospital bargaining units, attempting to group employees with similar functions and skills. Generally, the board recognized five units: registered nurses, other professionals, technical employees, service and maintenance workers, and business-office clerical (NLRB, 1988). Employers challenged these definitions as too narrow and appeals courts frequently overturned NLRB decisions (Gullett and Kroll, 1990). In a 1984 case (St. Francis II) the board adopted a "disparity of interest" test for unit determination (St. Francis Hospital, 271 N.L.R.B. 948, 953, 1984), permitting larger disparities between wages, hours, and working conditions than previously allowed. This change resulted in essentially two bargaining units: professional and nonprofessional employees (NLRB, 1988).

The decision in St. Francis II was appealed to the District of Columbia Circuit Court of Appeals, which ruled that the NLRB erroneously applied the disparity of interest test. After the case was remanded to the Board, the NLRB moved to a "rulemaking" approach, and in 1989 the Board established eight bargaining units in the health care industry: physicians, registered nurses, professionals except physicians and registered nurses, technical employees, skilled maintenance employees, business office clerical employees, guards, and other nonprofessional employees (NLRB, 1988). Psychiatric hospitals and nursing homes were not covered under the new rules and acceptable bargaining units in these sectors would be evaluated on a case-bycase basis. The American Hospital Association filed suit seeking to permanently 
enjoin the Board from enforcing the rule. The district court found the rules violated the congressional admonition to avoid undue proliferation and issued an injunction. The Seventh Court of Appeals, however, reversed the decision arguing that the rulemaking approach was sufficiently broad. Finally in April 1991, the Supreme Court affirmed the Seventh Circuit's decision in a unanimous opinion making the rule enforceable by the Board (American Hospital Association v. NLRB, $111 \mathrm{~S}$. Ct. 1539, 1991). Hence, the current standard is the rulemaking approach as outlined in 1989.

It was expected that the 1991 Supreme Court decision and the rulemaking approach to unit determination would strengthen union organization. Union representation is a collective good in that many of the services provided are nonrival and nonexcludable. That is, individual workers cannot be excluded from contract provisions covering layoffs, work rules, promotion or from commonly provided working conditions (safety, hours of work, etc.). The more similar are employees' preferences within a bargaining unit, the lower the cost of organizing and the easier it is for a union to provide a mix of "services" that can gain and maintain majority support. ${ }^{9}$

Schwarz and Koziara (1992) have examined how bargaining units affect wages, strikes, and jurisdictional disputes in hospitals. They find little, if any, evidence that an increased number of bargaining units leads to higher wage settlements. Only where there are 5 or 6 units (which occurs only about 7 percent of the time) are RN wages significantly higher than hospitals with only one bargaining unit. Hospitals with more than 6 units do not have wages significantly higher than those with only one unit. They find no relationship between bargaining units and the wages of LPNs and other health care workers.

Although it is difficult to evaluate the effects of NLRB unit determination on union organizing strength, there is little in the descriptive data presented in Table 5 that would suggest a large impact, a finding consistent with the results in Schwarz and Koziara. The only obvious breaks in the union election series are the increase in elections following the 1974 passage of Public Law 93-360, and the sharp drop in elections after 1981. The latter, of course, was an economy-wide phenomenon (Chaison and Dhavale, 1991), as seen in Table 5 by a relatively constant proportion of health service to economy-wide representation elections. And, not surprisingly, there are no obvious changes in CPS union membership density among our three groups of health care workers that can be ascribed to labor law changes.

Greater bargaining power may show up not only in increased membership, but also in larger union wage premiums or stronger union threat effects. We can mention briefly the results of estimating separate union wage premiums by time period (these results are not shown). For the health care sector as a whole, as well as for health technicians and workers in lower skill health service occupations, standard regression estimates of union wage premiums are remarkably stable over the 1973-1994 period. The one exception that we find is for hospital-based RNs, who realize an estimated union premium during the (pooled) 1992-1994 period of about 5 percent, as compared to a premium of about 2-3 percent during earlier years. Such evidence is consistent with enhanced bargaining power among hospital RNs following the Supreme 
Table 5

Union Organizing Activity and Membership Density in the Health Care Industry

\begin{tabular}{|c|c|c|c|c|c|c|c|c|c|c|}
\hline \multirow[b]{2}{*}{ Year } & \multicolumn{3}{|c|}{ Health Service Industry } & \multicolumn{4}{|c|}{ All Industries } & \multicolumn{3}{|c|}{ Union Density (\%) } \\
\hline & $\begin{array}{c}\text { Total } \\
\text { Elections }\end{array}$ & $\begin{array}{l}\text { \%Union } \\
\text { Wins }\end{array}$ & $\begin{array}{c}\text { Total } \\
\text { Votes Cast }\end{array}$ & $\begin{array}{c}\text { Total } \\
\text { Elections }\end{array}$ & $\begin{array}{c}\text { \%Union } \\
\text { Wins }\end{array}$ & $\begin{array}{c}\text { Total } \\
\text { Votes Cast }\end{array}$ & Ratio & RN & HT & HS \\
\hline 1966 & 6 & 50.0 & 291 & 8,324 & 60.8 & 534,454 & .001 & - & - & - \\
\hline 1967 & 6 & 83.3 & 369 & 8,116 & 59.0 & 554,133 & .001 & - & - & - \\
\hline 1968 & 108 & 81.5 & 4,098 & 7,857 & 57.2 & 566,164 & .014 & - & - & - \\
\hline 1969 & 135 & 62.2 & 4,714 & 7,993 & 54.6 & 526,419 & .017 & - & - & - \\
\hline 1970 & 153 & 64.1 & 6,680 & 8,074 & 55.2 & 531,402 & .019 & - & - & - \\
\hline 1971 & 225 & 67.1 & 10,708 & 8,362 & 53.2 & 514,284 & .027 & - & - & - \\
\hline 1972 & 250 & 62.0 & 10,818 & 8,923 & 53.6 & 519,477 & .028 & - & - & - \\
\hline 1973 & 254 & 64.6 & 12,826 & 9,369 & 51.1 & 480,303 & .027 & 6.0 & 8.2 & 10.1 \\
\hline 1974 & 248 & 60.9 & 11,997 & 8,858 & 50.0 & 482,414 & .028 & 8.0 & 9.6 & 12.4 \\
\hline 1975 & 579 & 59.8 & 41,828 & 8,577 & 48.2 & 501,996 & .068 & 9.8 & 9.9 & 12.4 \\
\hline 1976 & 710 & 58.6 & 53,671 & 8,638 & 48.1 & 418,347 & .082 & 12.1 & 8.1 & 13.8 \\
\hline 1977 & 746 & 54.7 & 58,947 & 9,484 & 46.0 & 504,241 & .079 & 11.9 & 12.7 & 14.0 \\
\hline 1978 & 596 & 54.4 & 43,100 & 8,240 & 46.0 & 417,563 & .072 & 15.0 & 12.0 & 14.1 \\
\hline 1979 & 528 & 53.0 & 40,482 & 8,043 & 45.0 & 506,040 & .066 & 14.8 & 14.5 & 16.0 \\
\hline 1980 & 695 & 50.6 & 62,812 & 8,198 & 45.7 & 458,114 & .085 & 19.7 & 9.5 & 13.6 \\
\hline 1981 & 653 & 52.5 & 55,591 & 7,512 & 43.1 & 392,157 & .087 & 17.4 & 8.6 & 14.3 \\
\hline
\end{tabular}


Table 5 - Continued

\begin{tabular}{|c|c|c|c|c|c|c|c|c|c|c|}
\hline \multirow[b]{2}{*}{ Year } & \multicolumn{3}{|c|}{ Health Service Industry } & \multicolumn{4}{|c|}{ All Industries } & \multicolumn{3}{|c|}{ Union Density (\%) } \\
\hline & $\begin{array}{c}\text { Total } \\
\text { Elections }\end{array}$ & $\begin{array}{l}\text { \%Union } \\
\text { Wins }\end{array}$ & $\begin{array}{c}\text { Total } \\
\text { Votes Cast }\end{array}$ & $\begin{array}{c}\text { Total } \\
\text { Elections }\end{array}$ & $\begin{array}{c}\text { \%Union } \\
\text { Wins }\end{array}$ & $\begin{array}{c}\text { Total } \\
\text { Votes Cast }\end{array}$ & Ratio & RN & HT & HS \\
\hline 1982 & 473 & 49.0 & 40,161 & 5,116 & 40.3 & 257,599 & .092 & - & - & - \\
\hline 1983 & 378 & 54.8 & 28,923 & 4,405 & 43.0 & 181,305 & .086 & 16.0 & 12.1 & 15.6 \\
\hline 1984 & 386 & 56.2 & 28,741 & 4,436 & 42.0 & 221,023 & .087 & 15.7 & 11.4 & 15.3 \\
\hline 1985 & 356 & 55.3 & 30,140 & 4,614 & 42.4 & 224,116 & .077 & 15.1 & 10.0 & 14.4 \\
\hline 1986 & 373 & 50.9 & 30,837 & 4,520 & 43.2 & 229,239 & .083 & 15.2 & 10.2 & 13.8 \\
\hline 1987 & 352 & 54.8 & 29,602 & 4,069 & 43.9 & 212,825 & .087 & 15.5 & 9.6 & 13.5 \\
\hline 1988 & 342 & 53.8 & 29,257 & 4,153 & 46.3 & 214,092 & .082 & 15.3 & 10.3 & 12.1 \\
\hline 1989 & 296 & 53.0 & 22,910 & 4,413 & 46.7 & 239,934 & .067 & 16.3 & 10.4 & 12.8 \\
\hline 1990 & 367 & 56.7 & 30,124 & 4,210 & 46.7 & 229,242 & .087 & 16.6 & 10.7 & 13.0 \\
\hline 1991 & 342 & 52.3 & 25,313 & 3,752 & 44.3 & 195,876 & .091 & 16.8 & 9.2 & 13.0 \\
\hline 1992 & 299 & 54.5 & 24,653 & 3,599 & 46.5 & 193,035 & .083 & 15.8 & 10.4 & 13.4 \\
\hline 1993 & 324 & 58.3 & 26,241 & 3,586 & 47.6 & 201,557 & .090 & 15.9 & 10.5 & 13.2 \\
\hline 1994 & - & - & - & - & - & - & - & 17.9 & 10.5 & 14.3 \\
\hline
\end{tabular}

Notes: Union elections data are from the National Labor Relations Board's Annual Reports 1966-1993, Table 16. Total Elections is the total number of elections in the fiscal year ending September 30. \% Union Wins is the percent of elections in which representative rights were won by unions, and Total Votes Cast is the total number of votes cast in the elections. Ratio is the ratio of health service industry union elections to total union elections in all industries. Union Density data are from the CPS ORG files. Union membership is not available for 1982. Health Technicians (HT) includes clinical laboratory technologists and technicians, dental hygienists, health record technologists and technicians, radiologic technicians, licensed practical nurses, and health technologists and technicians n.e.c. Health Service Occupations (HS) include dental assistants, health aides except nursing, and nursing aides, orderlies, and attendants. 
Court's 1991 decision. However, because the absolute levels of the premiums are low and the change over time is small relative to the standard error of the estimates, we are reluctant to attach heavy weight to such evidence. Likewise, we previously noted that estimated union threat effects (measured by the impact of local area union density on the wages of nonunion workers) show a small increase in the impact of unions on nonunion wages after 1991, again consistent with enhanced union power following the Supreme Court decision. Absent stronger evidence, we are reluctant to ascribe our wage results to the shift in NLRB rules on hospital organizing. A more conclusive determination of the effects of NLRB policy must await further evidence.

\section{Conclusions}

We have provided an analysis of union effects in health care labor markets. Consistent with previous research, we find that standard union wage premium estimates are substantially smaller for health care workers than for workers outside the health care sector, and are smaller among RNs than among lower skill health care workers. Longitudinal analysis controlling for worker-specific abilities also shows small union effects in health care markets. In contrast to the wage level evidence, longitudinal results indicate only small differences in union premiums across skill groups. Much of the observed union wage advantage among workers in lower skilled health occupations is not a rent but, rather, compensation for high unmeasured skills. Wage premiums create queues for union jobs and employers avoid hiring workers with very low skills. Because of union wage standardization and limited merit-based wage dispersion, however, workers who are most able are least likely to select union jobs. Thus, while high unmeasured skills owing to employer selection account for much of the union wage advantage among workers with low levels of measured skills, unionnonunion differences in unmeasured skills are less important among workers with higher levels of measured skills.

Taken together, our evidence indicates that labor union effects on wages in health care labor markets are small, regardless of whether they are estimated in levels or changes. During the 1980s health care expenditures were rising rapidly, and the earnings of health care workers (especially RNs) were increasing in both real and relative terms. Despite the favorable economic climate, unions had a rather modest impact on the earnings of union and nonunion health care workers. We find no clear-cut evidence of a large impact from recent changes in bargaining unit determination within hospitals, although our results hint at some increased union bargaining power after 1991.

While it is difficult to predict what will occur over the next several years, our results suggest that the AFL-CIO's attempts to organize in the health care industry will have limited success. The increased competitiveness of the health care sector and a slowdown in demand growth for hospital-based health care workers suggest that union organizing ability and bargaining power may in fact diminish. If unions were unable to obtain significant wage gains for their members in an economic environment relatively conducive to bargaining, it is unlikely that the union impact will increase in a more competitive environment. In the short run unions may be effective 
in maintaining existing wages levels for their members, and union-nonunion wage differentials may increase owing to greater downward wage flexibility among nonunion health care workers. Likewise, increased risks of job and wage loss accompanying changes in health delivery systems may increase worker interest in organizing. In the long run, however, sizable union wage premiums will be difficult to sustain. The ultimate role of unions in a more competitive health care sector will hinge on the degree of cooperation and conflict in the labor relations environment, the relative productivity of union and nonunion establishments, and the success of human resource practices that prevail in union and nonunion work sites. ${ }^{10}$ 


\section{Appendix 1}

Cross-Sectional Regression Results

\begin{tabular}{|c|c|c|c|}
\hline & $\begin{array}{l}\text { Registered } \\
\text { Nurses }\end{array}$ & $\begin{array}{c}\text { Health } \\
\text { Technicians }\end{array}$ & $\begin{array}{c}\text { Health } \\
\text { Service } \\
\text { Occs }\end{array}$ \\
\hline Union Membership & $\begin{array}{c}0.032 \\
(0.005)\end{array}$ & $\begin{array}{c}0.049 \\
(0.007)\end{array}$ & $\begin{array}{c}0.114 \\
(0.005)\end{array}$ \\
\hline Hospital & $\begin{array}{c}0.159 \\
(0.004)\end{array}$ & $\begin{array}{c}0.067 \\
(0.004)\end{array}$ & $\begin{array}{c}0.146 \\
(0.004)\end{array}$ \\
\hline Public & $\begin{array}{c}0.019 \\
(0.004)\end{array}$ & $\begin{array}{l}-0.014 \\
(0.006)\end{array}$ & $\begin{array}{c}0.067 \\
(0.005)\end{array}$ \\
\hline Schooling & $\begin{array}{c}0.033 \\
(0.001)\end{array}$ & $\begin{array}{c}0.074 \\
(0.001)\end{array}$ & $\begin{array}{c}0.041 \\
(0.001)\end{array}$ \\
\hline Experience & $\begin{array}{c}0.013 \\
(0.001)\end{array}$ & $\begin{array}{c}0.018 \\
(0.001)\end{array}$ & $\begin{array}{c}0.011 \\
(0.000)\end{array}$ \\
\hline $\operatorname{Exp}^{2} / 100$ & $\begin{array}{l}-0.027 \\
(0.001)\end{array}$ & $\begin{array}{l}-0.033 \\
(0.001)\end{array}$ & $\begin{array}{l}-0.021 \\
(0.001)\end{array}$ \\
\hline Black & $\begin{array}{l}-0.095 \\
(0.007)\end{array}$ & $\begin{array}{l}-0.055 \\
(0.007)\end{array}$ & $\begin{array}{l}-0.078 \\
(0.004)\end{array}$ \\
\hline Male & $\begin{array}{c}0.028 \\
(0.008)\end{array}$ & $\begin{array}{c}0.070 \\
(0.006)\end{array}$ & $\begin{array}{c}0.045 \\
(0.006)\end{array}$ \\
\hline $\begin{array}{l}\text { Married, Spouse } \\
\text { Present }\end{array}$ & $\begin{array}{c}0.015 \\
(0.005)\end{array}$ & $\begin{array}{c}0.057 \\
(0.006)\end{array}$ & $\begin{array}{c}0.069 \\
(0.005)\end{array}$ \\
\hline $\begin{array}{l}\text { Divorced, Separated, } \\
\text { or Widowed }\end{array}$ & $\begin{array}{c}0.015 \\
(0.006)\end{array}$ & $\begin{array}{c}0.028 \\
(0.007)\end{array}$ & $\begin{array}{c}0.026 \\
(0.005)\end{array}$ \\
\hline Large Metropolitan Area & $\begin{array}{c}0.102 \\
(0.004)\end{array}$ & $\begin{array}{c}0.099 \\
(0.005)\end{array}$ & $\begin{array}{l}0.115 \\
(0.004)\end{array}$ \\
\hline Part-1ime Status & $\begin{array}{c}0.007 \\
(0.004)\end{array}$ & $\begin{array}{c}0.002 \\
(0.005)\end{array}$ & $\begin{array}{l}-0.029 \\
(0.004)\end{array}$ \\
\hline Adj. $R^{2}$ & 0.187 & 0.222 & 0.216 \\
\hline Sample Size & 38,555 & 29,594 & 45,044 \\
\hline
\end{tabular}

Notes: Data are from the May CPS supplements for 1973-1981 and the CPS ORG files for 1983-1994. Union data are not available in the CPS for 1982. RN is registered nurses; Tech is health technicians; HS is health services occupations; and other variables included in the regressions were dummies for other race, region (8) and year (19). Results for union membership and hospital correspond to those shown in Table 2. Standard errors are in parentheses. 


\section{Appendix 2}

\section{Construction of the Longitudinal Sample from the CPS ORG Files}

The CPS sample design is such that households are included in 8 surveys (rotation groups), beginning with 4 consecutive months in, followed by 8 months out, followed by 4 months in. Outgoing rotation groups 4 and 8 are asked earnings supplement questions (weekly earnings, hours, union status, etc.). The CPS contains household identification numbers (ID) and record line numbers, but not individual identifiers. Individuals potentially can be identified for the same month in consecutive years; that is, individuals in rotation 4 in year 1 can be matched to individuals in rotation 8 in year 2 .

The longitudinal ORG file was created in the following manner. Separate data files were created for males and females, and for pairs of years (rotation 4/1983 and rotation 8/1984, rotation 4/1984 and rotation 8/1985, etc.). Within each file, individuals were sorted as appropriate on the basis of ascending and descending household ID, year, and age. To be considered an acceptable matched pair, a rotation 8 individual had to be matched with a rotation 4 individual with identical household ID, identical survey month, and an age difference between 0 and 2 (since surveys can occur on different days of the month, age change need not equal 1). Several passes were necessary because a single household may contain more than one male or female pair. Checks were provided to insure that only unique matches were selected. For each rotation 8 individual, the search was made through all rotation 4 individuals with the same ID to make sure there was only 1 possible match; the file was resorted in reverse order and each selected rotation 4 individual was checked to insure a unique rotation 8 match. As uniquely matched pairs were identified they were removed from the work file. Incorrect changes in the variables marital status, veteran status, race, and education (e.g., a change in schooling other than 0 or 1 , a change from married to never married, etc.) were used to delete "bad" observations in households where there were multiple observations and ages too close to separate matched pairs. Several passes at the data were made. In households where two pairs of individuals could be separated based on a 1 year but not the 0 to 2 year age change, a 1 year criterion was used. If a unique pair could not be identified based on these criteria, they were not included in the data set (e.g., four observations with two identical pairs, or three individuals with two possible matches using the 0 to 2 age change criterion).

There are several reasons why matches cannot be made or that individual worker pairs are not included in the CPS ORG panel. The principal reasons are if a household moves (thus changing the household ID), if an individual moves out of a household, if a worker becomes self employed, if an individual drops out of the labor market or fails to meet other sample selection criteria, or if the Census is unable to reinterview a household and/or receive information on the individual. Inclusion rates for the entire CPS ORG panel are just under two-thirds of employed wage and salary workers in any year; rates are somewhat lower in our RN sample. Peracchi and Welch (1995) analyze attrition rates among matched March CPS files and conclude that age is the most important determinant of a successful match. Other factors that lessen match probabilities are poor health, low schooling, and not a household head, while gender and race are unimportant match predictors following control for other factors. Finally, sample sizes are reduced further to roughly half the normal size for the $1984 / 5$ panel and to one-quarter for $1985 / 6$. This is the result of a CPS test sample from July-September 1985 that implemented new population weights. Rotation 4 households interviewed in July 1984 through September 1985 were not reinterviewed a year later in 1985 and 1986. 


\section{NOTES}

*The authors appreciate the assistance of David Macpherson, who helped develop the CPS data files used in the paper.

${ }^{1}$ Calculations from the CPS indicate that nurses (RNs, LPNs, and nursing aides) comprise close to 40 percent of total hospital wage and salary employment. In 1994, 7 percent of all full-time female wage and salary workers were employed in nursing (Employment and Earmings, January 1995, Table 56).

${ }^{2}$ Means above the earnings cap are taken from Hirsch and Macpherson (1996, p. 6), who estimate annual gender-specific values from the Pareto distribution. Means in nominal dollars are roughly $\$ 1,500$ for years with a $\$ 999$ cap and $\$ 3,000$ for years with a $\$ 1,923$ cap, with moderately higher values for men than women and increases in the means over time.

${ }^{3}$ Health Technologists and Technicians include clinical laboratory technologists and technicians, dental hygienists, health record technologists and technicians, radiologic technicians, licensed practical nurses, and health technologists and technicians, n.e.c. Health Service Occupations include dental assistants, health aides except nursing, and nursing aides orderlies, and attendants.

${ }^{4} \log$ differentials can be converted to approximate percentage differentials by [exp $\left.(d)-1\right] 100$, where $d$ is the log differential. Information on collective bargaining coverage, defined as all union members plus nonmembers who say they are covered by a collective bargaining agreement, is available beginning in 1977 . Union coverage density is about 2 percentage points higher than is membership density.

${ }^{5} \mathrm{~A}$ simple specification is used for ease of exposition. Union differential estimates based on separate union and nonunion wage equations are highly similar. We do not consider the issue of union endogeneity. Subsequent longitudinal analysis controls for worker specific skills and thus corrects for some forms of selectivity bias.

${ }^{6}$ Since sample sizes for the years prior to 1983 are small, we include three-year group dummies for these years (1973-1975 is the omitted group) and separate year dummies for 1983 and after.

${ }^{7}$ Jakubson (1991) finds no evidence that the first differencing technique outlined above is an overly restrictive specification of the model when applied to union status.

${ }^{8}$ For the comparison groups we include four separate measures for the change in union status. Among those who reported changing union status we included separate variables for those who also changed occupation and industry, those who changed occupation but not industry, those who changed industry but not occupation, and those who changed neither occupation or industry. The coefficients reported in the table are for those who changed both occupation and industry. As shown in Hirsch and Schumacher (1998), this group is least likely to have changes in union status reported with error and its coefficient provides the most reliable longitudinal estimate.

${ }^{9}$ For a discussion along these lines, see Hirsch and Addison (1986). Demsetz (1993) provides an explicit test for this thesis, finding that skill-homogeneous groups are more readily organized than skill-heterogeneous groups. We should note that the 1991 decision is not the only one affecting union organizing of health care workers. In a 1994 decision, NLRB v. Health Care and Retirement Corporation of America (HCR) (92 S. Ct. 1964, 1994), the Supreme Court upheld a federal circuit court decision that LPNs at an Ohio nursing home were supervisory employees and not covered by the legal protections of the NLRA. Justice Kennedy, author of the 5-4 majority decision, emphasized that the findings in this case were limited to health care workers.

${ }^{10}$ Register (1988) provides evidence finding that union hospitals are more productive than nonunion hospitals. This study is notable because it is one of the few studies that find positive union productivity effects in a not-for-profit or relatively noncompetitive sector. 


\section{REFERENCES}

Abowd, John S., and Henry S. Farber. "Job Queues and the Union Status of Workers." Industrial and Labor Relations Review 35 (April 1982): 354-67.

Adamache, Killard W., and Frank A. Sloan. "Unions and Hospitals, Some Unresolved Issues." Journal of Health Economics 1 (May 1982): 81-108.

Brown, Charles. "Equalizing Differences in the Labor Market." Quarterly Journal of Economics 94 (February 1980): 113-34.

Bruggink, Thomas H., Keith C. Finan, Eugene B. Gendel, and Jeffrey S. Todd. "Direct and Indirect Effects of Unionization on the Wage Levels of Nurses: A Case Study of New Jersey Hospitals." Journal of Labor Research 6 (Fall 1985): 405-16.

Cain, Glen G., Brian E. Becker, Catherine G. McLaughlin and Albert E. Schwenk. "The Effect of Unions on Wages in Hospitals." In Research in Labor Economics, edited by Ronald Ehrenberg, Vol. 4. Greenwich, Conn.: JAI Press, 1981, pp.191-320.

Chaison, Gary N., and Dileep G. Dhavale. "A Note on the Severity of the Decline in Union Organizing Activity." Industrial and Labor Relations Review 43 (April 1990): 366-73.

Demsetz, Rebecca S. "Voting Behavior in Union Representation Elections: The Influence of Skill Homogeneity and Skill Group Size." Industrial and Labor Relations Review 47 (October 1993): 99-113.

Feldman, Roger, and Richard Scheffler. "The Union Impact on Hospital Wages and Fringe Benefits." Industrial and Labor Relations Review 35 (January 1982): 196-206.

Freeman, Richard B. "Unionism and the Dispersion of Wages." Industrial and Labor Relations Review 34 (October 1980): 3-23.

"The Effect of Unionism on Fringe Benefits." Industrial and Labor Relations Review 34 (July 1981): 489-509.

Gullett, C. Ray, and Mark J. Kroll. "Rule Making and the National Labor Relations Board: Implications for the Health Care Industry." Health Care Management Review 15 (Spring 1990): 61-65.

Gibbons, Robert, and Lawrence F. Katz. "Does Unmeasured Ability Explain Inter-Industry Wage Differentials?” Review of Economic Studies 59 (July 1992): 515-35.

Hirsch, Barry T., and John T. Addison. The Economic Analysis of Unions: New Approaches and Evidence. Boston, Mass.: Allen \& Unwin, 1986.

Hirsch, Barry T., and David A. Macpherson. Union Membership and Earnings Data Book: Compilations from the Current Population Survey (1996 Edition). Washington, D.C.: Bureau of National Affairs, 1996.

Hirsch, Barry T., and Edward J. Schumacher. "Monopsony Power and Relative Wages in the Labor Market for Nurses." Journal of Health Economics 14 (November 1995): 443-76. . "Unions, Wages, and Skills." Journal of Human Resources 33 (Winter 1998).

Jakubson, George. "Estimating and Testing of the Union Wage Effect Using Panel Data." Review of Economic Studies 58 (October 1991): 971-91.

Lewis, H. Gregg. Union Relative Wage Effects: A Survey. Chicago: University of Chicago Press, 1986.

Mackender, Darin. "Harmony in the Health Care Industry at Last? American Hospital Association v. National Labor Relations Board, 111 S. Ct. 1539 (1991).” Nebraska Law Review 71 (1992): 937-63.

National Labor Relations Board. "Collective Bargaining Units in the Health Care Industry: Second Notice of Proposed Rulemaking.” 29 C.F.R. 103: 33905, 33934, 1988. 
Neumark, David, and Michael L. Wachter. "Union Effects on Nonunion Wages: Evidence from Panel Data on Industries and Cities." Industrial and Labor Relations Review 49 (October 1995): 20-38.

Peracchi, Franco, and Finis Welch. "How Representative are Matched Cross Sections? Evidence from the Current Population Survey.” Journal of Econometrics 68 (July 1995): 153-80.

Register, Charles A. "Wages, Productivity, and Costs in Union and Nonunion Hospitals." Journal of Labor Research 9 (Fall 1988): 325-45.

Rosenthal, Elisabeth. "New York Hospitals Cut Costs by Laying Off Nurses." New York Times, August 19, 1996.

Schumacher, Edward J., and Barry T. Hirsch. "Compensating Differentials and Unmeasured Ability in the Labor Market for Nurses: Why Do Hospitals Pay More?" Industrial and Labor Relations Review 50 (July 1997): 557-79.

Schwarz, Joshua L., and Karen S. Koziara. "The Effect of Hospital Bargaining Unit Structure on Industrial Relations Outcomes.” Industrial and Labor Relations Review 45 (April 1992): 573-90. 